症例

\title{
閉鎖孔へル
}

日本大学第 1 外科学教室

春日棌市立病院外科

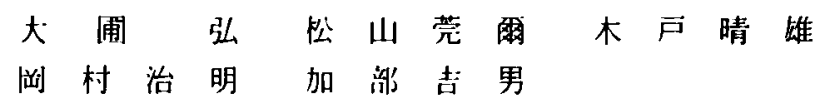

\section{THREE CASES OE THE OBTURATOR HERNIA}

Nobuhiko TANAKA

First Department of Surgery, Nihon University School of Medicine

Hiroshi OHHATA, Kanji MATSUYAMA, Haruo KIDO,

Haruaki OKAMURA and Yoshio KABE

Department of Surgery, Kasukabe City Hospital

閉鎖孔へルニフの3 手術例を報告する.

〔症例 1】81歳の女性. 1 年 9 カ月前にイレウスの保存的療法の既往あり，今回も1 レゥスの診断で入院, 体重31kg, 症状が軽いため保存的に経過を観察するす軽快せず， 手術を行った，左閉鎖孔へルニフのRichter 型嵌頓であった，回腸切除兼へルニフ震の 結節繾合を施行した. 㭪後 3 年 6 カ月後再発し, 腸切除術兼へルニフ門䋖合で治㦄した。

【症例 2〕73歳女性. 原因不明のイレゥスとして内科より転科し手術施行．右側閉鎖 孔へルニフの Richter 型嵌頓でありヘルニフ門の䋖縮を行い治范した。

【症例 3] 88蔵女性. 1 年前に Saint's triad のため手術の既往があり, 瘦着性イレゥ スの診断で手術を行ったところ, 右側閉鎖孔へルニアの Richter 型诶頓で, 回腸切除兼へ ルニア門䋖縮を行ない治拻した。

以上の 3 症例とも老龄のやせた女性であり，一般状態す覀く、イレゥスの原因を充分 に検索することができなかった，直腸指診では全例ともへルニフによる畽瘤は触知でき なかった。しかし，本症の特徽とされる Howship-Romberg signは術後詳細に問診する と再発時を除き全例に認められ，反省させられた。

本症の本邦報告例136例の集計も併せ行ったが,術前診断例は寲診例を含めて $24.4 \%$ に 過ぎず，転㷌では死亡が23.7\%，最近10年間の報告例58例でも15.3\%と高い值であった。 これは，患者が高龄で一般状態が悪く診断がむずかしく，乙かも腸切除例が $62 \%$ にも達 することにも起因すると考えられる。

高齢者でやせており，原因不明のイレゥスに遭遇したら，本症もその原因の一つであ ることを考㦄して早期に診断するように心卦ける必要がある。

手術々式では，患者の一般状態や局所々見が許せば，腹膜の䋖合のみならずへルニア 門を閉鎖する術式が望ましい。 
はじめに

閉鎖孔へルニアは老㱓者にみられる比較的稀な疾患 とされており，本邦では尼川”，菅野2)らによって1977 年 4 月まで93例の集計がなされている. 今後の高龄者 社会への移行につれて本症も増加するものと思われ る.われわれは本症の 3 例を経験したのでその症例の 概要を報告するとともに，菅野以降の報告例を加え合 計136例の本邦報告例を集計し得たので，これらをると に若干の文献的考察を加えたい。

\section{症例}

症例は昭和48年11月より53年 8 月までに春日部市立 病院外科で手術した閉鎖孔へルニフの3 症例である (表 1).

症例 $1: 81$ 歳。女性.

主訴：腹痛, 呕吐

既往歴: 今回の入院の 1 年 9 力月前と 10 力月前の 2 回原因不明のイレゥスにて当院内科および外科に入院 し，そのつぞ保存的治療で宽解した既往がある，両側 坐骨神経痛，分婏 2 回。

現病歴：今回の入院の 8 日前から腹痛と呕吐が出現 し，某医より当科へ紹介されイレゥスの診断で入院と なる。

入院時所見：体重 $31 \mathrm{~kg}$, 栄羡不良, 顔貌苦閵状, 意 識無欲状，口䐁内乾燥あり，軽度に脱水がある．腹部 所見では下腹部膨満之腸雑音の亢進を認める，血液一 般検査では軽度の董血と低蛋白血症があり，腹部単純 $\mathrm{X}$ 線写真では小腸ガス像之水平像があり，大腸ガス像 はほとんどみられなかった。

入院経過：入院後保存的治療で経過をみたがイレウ ス症状は増強するため第 5 病日，発症より12日目に手 術を行った。

手術所見：下腹部正中切開で開腹すると拡張した腸 管があり，回腸末端から $100 \mathrm{~cm}$ 口側の回腸が左閉鎖孔 に宿入校拒された Richter 型牥頓で，周囲は硬く瘜着

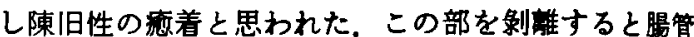
壁は壞死に宿っており，同部を含めて $20 \mathrm{~cm}$ 腸切除し， 端々吻合した。へルニフ門周囲は硬くへルニフ暻を切 除することなくへルニフ門の腹膜を結節耗合して䦥鎖 を行った。

術後 3 年 6 力月して再びイレゥス症状をきたし来䬧 した. 閉鎖孔ールニアの再発も考えたが HowshipRomberg signがなく，直腸指診です腫瘤を知しな かったため，康着性イレゥスの診断で保存的治療を施 行したがイレウス状態は改善せず，発症より7日目に 手術を行った。

手術所見：左閉鎖孔へルニフの再発でありトライッ 靬帯より肛門側 $100 \mathrm{~cm}$ の空腸が左閉鎖孔に Richter 型嵌頓し校扼されていた，空腸を $20 \mathrm{~cm}$ 切除して端々 吻合し、へルニフ門は閉鎖孔の耗縮により閉鎖した。

症例 $2: 73$ 歳, 女性

主訴：呕吐

既往歴：50歳頃上り右坐骨神経痛，高血圧症，分娩 2 回.

現病歴：感冒治療中呕吐をきたし当院内科に入院， イレウスと診断され外科で注腸造影を施行したがその 原因は明らかにならず，保存的治療法では改善せず， 却ってイレウス症状が増強するため第 6 病日外科に転 科した。

入院時所見：体重 $35 \mathrm{~kg}$ ，栄養不良で下腹部は軽度䁗 满し，金属性腸雑音が聴取された。血夜一般検查では 軽度の賓血之低蛋白血症が認められた。腹部単純 X 線 写真では小腸ガス像と水平像が認められ結腸ガス像は 少なかった．注晹造影では回腸末端より口側 $60 \mathrm{~cm}$ で造影されたが、この範囲の異常は発見されなかった。

入院経過：原因不明のイレウスとして保存的治療を 行ったが，イレウス状態は改善されず発症より10日後 に手術が行なわれた。

手術所見：中腹部正中切開にて開腹した。腹水な

表1 閉鎖孔ヘルニア自験例

\begin{tabular}{|c|c|c|c|c|c|c|}
\hline 症例 & $\begin{array}{l}\text { 年龄 } \\
\text { (瓷) }\end{array}$ & 左右 & $\begin{array}{l}\text { 発 } \\
\text { 症 } \\
\text { (日) } \\
\text { (日) }\end{array}$ & 術前診断 & 手術々式 & $H \cdot R^{*}$ \\
\hline \multirow{2}{*}{ (再発) } & 81 & 左 & 12 & $1 レ ウ \pi$ & ヘルニア震維合 腸切除 & $(+)$ \\
\hline & 85 & 左 & 7 & 萝着性イレゥス & ヘルニア門䋖合 晹切除 & $(-)$ \\
\hline 2 & 73 & 右 & 10 & イレウ ス & ヘルニア門䋖合 & $(+)$ \\
\hline 3 & 88 & 右 & 16 & 窝着性イレウス & ヘルニテ門維樎 腸切除 & $(+)$ \\
\hline
\end{tabular}


し.小腸の拻張が広範囲にみられ回腸末端より $70 \mathrm{~cm}$ 口側部が右閉鎖孔に Richter 型のールニフ㛣顿をきた していた，同部を爱護的に引き出すと腸管には循環障 害はみられず腸妡除は施行しなかった。閉鎖孔の結節 維合でヘルニフ門を閉鎖した。

症例 $3: 83$ 歳, 女性

主訴：腹痛, 呕吐

既往歴: 1 年前 Saint's triadのため胆乘摘出術と 食道裂孔䌊縮術を受けている，右坐骨神経痛，分婏 5 回.

現病歴：入院 4 日前より便秘をきたし自宅で完腸を 柂行して様子をみていたがさらに腹痛，呕吐をきたし 当科内科入椟着性イレウスの診断で入院した。保存的 療法を試みたが軽快せず第11病日低ナトリウム性の電 解質失調をきたし，電解質補正後第12病日に外科へ転 科した。

入院時所見：体重 $40 \mathrm{~kg}$ ，栄養不良，腹部剅満著明に て腸䌖音の亢進を認める。血液一般生化学検査所見で は低蛋白血症がみられた。腹部単純 X 線写真では著明 な小腸ガス像と水平像を認めた。

入院経過：外科入転科後直ちに手術を行った。

手術所見：下腹部正中切開で開腹した。血性腹水が 中等量あり，小腸は著明に拡張しており回腸末端より 口側 $150 \mathrm{~cm}$ の部が右閉鎖孔に Richter 型のヘルニフ

表 2 本邦報告例（136例）

\begin{tabular}{|c|c|c|}
\hline \multicolumn{3}{|l|}{ 年 嵀 } \\
\hline 生後32日 -91歳 & 平均71歳 & \\
\hline 60 歳以上 $86 \%$ & & \\
\hline \multicolumn{3}{|l|}{ 別 } \\
\hline 男 性 & & 7 例 $(5.3 \%)$ \\
\hline 女 生 & & 124 例 (94.7\%) \\
\hline 左右別 & & $\mathscr{6}$ \\
\hline 右 側 & & 65 例 (54.2\%) \\
\hline 左 側 & & 53 例 (44.2\%) \\
\hline 両 㑡 & & 2 例 $(1.7 \%)$ \\
\hline \multicolumn{3}{|l|}{ 術前彭断 } \\
\hline イレゥス & & 76 例 (61.8\%) \\
\hline 閉銷孔ヘルニア & & 30 例 (24.4\%) \\
\hline 大鹏へルニア & & 5 例 (4.1\%) \\
\hline 急性虫垂炎 & & 5 例 (4.19\%) \\
\hline その他 & & 7 例 $(5.7 \%)$ \\
\hline \multicolumn{3}{|c|}{ Howship Romberg Sign } \\
\hline 陽生例 & & 79 例 (58.1\%) \\
\hline \multicolumn{3}{|l|}{ 䛔 憎 } \\
\hline 治 & & 87 例 (73.7\%) \\
\hline 死亡 & & 28 例 (23.7\%) \\
\hline 再 発 & & 4 例 (2.9\%) \\
\hline
\end{tabular}

嵌頓をきたしていた，嵌頓腸管は血行障害があり，整 復する際に穿孔をきたしたので穿孔部を含めて腸管を $20 \mathrm{~cm}$ 切除し，端々吻合を行った。閉鎖孔は結節縫合で 閉鎖した。

以上 3 例とも術後経過は良好で治瘁退院した。

$$
\text { 考按 }
$$

閉鎖孔へルニフは主に高龄者に発症する比較的稀な

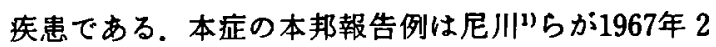
月まで53例，菅野2)らがそれ以降より1977年 4 月まで 40例を集計した。われわれは营野らの集計以降1980年 8 月までの43例を集計した ${ }^{3) ~ 20)}$. 尼川, 荌野らの集計 と併せると本邦報告例は136例となった（表 2)，以下 の本邦報告例はこれら136例の集計について述べる.

これらの報告例を最近の 10 年間，その前 10 年間，そ れ以前の 3 群に分けてみると報告例は增加の㑯向があ る(表 3).本疾患嵪踰者に多い疾患であり今後予想 される高齢化社会では上り重要な疾患となることが考 えられる。

本症はやせた高龄女性に多いのが特徵で，女性は男 性の 6 倍の頻度で発症するとされている22). 本邦の集 計では年龄は生後32日の特殊な例23)除き大部分が高 龄者で60歳以上が86\%，平均71歳であった。性別では ほとんどが女性で94.7\%であった，左右別では若干右 側に多く，2 例に両侧発生をみている（表 2).

本症の成因は，るい瘦による骨盤内脂肪織，特に閉 鎖孔内脂肪織の减少と老化や妊娠などで骨盤内支持組 膱や腹が弛縟することによると考えられている，女 性に願度の高い理由は妊娠，分婏々の関保の他に閉鎖 孔の横径の大きいことと骨盤の形状が男性に比し扁平 なことす関保しているとされている22).

本症のヘルニフ門となる閉鎖孔は小さく径 1２ $\mathrm{cm}$ のむのが多く，腹膜がールニア衰となり，小腸が ルニフ内容となる22)。この小さなールニフ門に小腸壁 が Richter 型ヘルニフ嵌頓を呈することにより急性小 腸イレウスの症状が発現する。これは時に宽解するこ ともあり，同様のイレウス発作をくり返するのもあ

表 3 本邦報告例の策計

一年代別，診断率・死亡率一

\begin{tabular}{c|c|c|c}
\hline & -1960 年 & -1970 年 & $\sim 1980$ 年 \\
\hline 集計 例数 & 23 例 & 39 例 & 64 (列 \\
\hline 術前晾断率 & $\begin{array}{c}1 / 23 \\
(4.3 \%)\end{array}$ & $\begin{array}{c}12 / 37 \\
(32.4 \%)\end{array}$ & $\begin{array}{c}17 / 54 \\
(31.5 \%)\end{array}$ \\
\hline 死 ᄃ 率 & $\begin{array}{c}10 / 22 \\
(45.5 \%)\end{array}$ & $\begin{array}{c}9 / 38 \\
(23.7 \%)\end{array}$ & $\begin{array}{c}9 / 58 \\
(15.3 \%)\end{array}$ \\
\hline
\end{tabular}


表 4 手術方法 (日影 ${ }^{30)}$ )

1. ヘルニア門到速法
(1) 開腹法
(2) 恥骨上切開法
(3) 単径法
(1) 大腿法

2. ヘルニア夏わよび門に対する処置

(1) 壁侧腹膜結節䋖合

(2) 閉銷孔入口部 (妇) の結節維合閉鎖

(3) 宣内翻，基部をタバコ維合，莫切除

(4) 子宮、卵果綎着

(5) パッ千法

る22)25). われわれの経験した症例 1 においても，2回の イレウス発作の既往がみられた.

本症に特徽的な随伴症状として，閉鎖孔を通る閉鎖 神経の王迫症状である Howship-Romberg signがあ る22126).これは大腿内側から粶部にかけての疼痛と知 覚異常で，本邦報告例では58.1\%に陽性であった（表 3).しかし術前に Howship-Romberg signに気付い た例は少なく，大部分が坐骨神経痛，関節リウマチと して処理されていて術後の詳細な病歴聴取により確認 し得たすのである。われわれの 3 症例です術前患者よ りはっきりした病歴聴取ができず，いずれも術後患者 やその家族，または紹介医より Howship-Romberg signが確認されたものであり反省させられた点であ る.

本症の診断においては，まず本疾患を念頭に置くこ とが大切であり，より詳細な病歴聴取により Howship-Romberg signの存在を確認することが重要であ る. 他覚的所見としては直腸指診, 内診にて閉鎖孔部 に腫瘤を触知することがあるとされている2427)，腹部 単純 X 線写真では小腸イレウス像と稀に閉鎖孔付近 に限局した小腸ガス像をみることがある28).とくに小 腸造影で小腸の閉鎖孔への陥入像を得たという報告む
ある ${ }^{11) 15) 28) 291}$ ．自倹例での症例 1 の再発時や症例 3 の よらに開腹術の既往があると磨着性イレウスと診断さ れやすいか，本邦報告例では術前診断の多くが原因不 明のイレウス76例 (61.8\%) で正診例は30例 (24.4\%) であった(表 3 )。本邦報告例を10年毎に区切ってみる と正診率は1960年以前が4.3\%であったが,これ以後は 30\%以上になっている（表 3 ).

本症の手術々式は種々挙げられるか;，日野ら 4 のよ5に分類している。ヘルニア門への到達法では， 本症の大多数の症例が原因不明のイレウスとして手術 されるので開腹法が多い，自験例 3 例すいずれる開腹 法であった．また術前に閉鎖孔ールニアの診断のつい た例ではへルニア門に容易に到達でき，また開腹を必 要とする場合る簡単である耽骨上切開法が良いとされ ている. ヘルニフ罴及び門に対する処置としてはへル ニフ美を切除しヘルニア門を䋖合閉鎖する術式が望ま しく，これが充分に行い得ない場合は子宮や卵巣を释 着する方法る再発防止上意義がある。しかし患者の状 態が必ずしす良好でなく，へルニフ等側腹膜）の 結節䋖合のみに終る例す多い。

本症の死亡率は高く本邦報告例では27.3\%であっ た。しかし報告例を10年毎に区切ってみると死亡率は 1960 年以前が $45.5 \%$ その後の 10 年間が $23.7 \%$, 最近の 10年間では15.7\%と減少してきている（表3）.

本症の再発について10\%の再発率を掲け゚ている文 献 ${ }^{311}$ あるか;, 近年では再発の報告は少ない.これは本 症の報告数自体が少なくしかも短期間の経過しかみて おらず長期の経過を追えぱ再発率は増加するとも考点 られる。本邦での再発例はわれわれの調査し得た籍囲 では, 武沼 ${ }^{32)}$, 菅野 ${ }^{16)}$, 桜井 ${ }^{6)}$ らの報告と自験例の計 4 例 $(2.9 \%$ ）の報告がある（表 5 ）。この5ち3例がへ

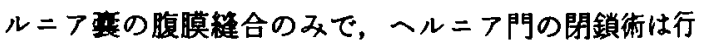
われておらず，術啳 7 カ月から 3 年 6 カ月で再発をき

表 5 再発報告例

\begin{tabular}{|c|c|c|c|c|c|c|c|c|}
\hline 報告者 & \begin{tabular}{|l|} 
年紫 \\
性
\end{tabular} & 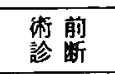 & $\begin{array}{l}\text { 閉銷孔の } \\
\text { ききさ }\end{array}$ & $\begin{array}{l}\text { 第一回 } \\
\text { 手術々式 }\end{array}$ & $\begin{array}{l}\text { 再発まで } \\
\text { の期間 }\end{array}$ & $\begin{array}{l}\text { 再 発 時 } \\
\text { 街前診断 }\end{array}$ & $\begin{array}{l}\text { 第二回 } \\
\text { 手蔽々式 }\end{array}$ & 転㷌 \\
\hline 武沼 ${ }^{321}$ & $\begin{array}{c}\text { 61歳 } \\
\text { 女 }\end{array}$ & イレウス & & 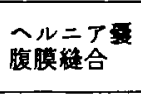 & 8 力月 & イレウス & 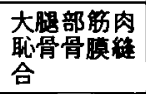 & 治窝 \\
\hline 营野 ${ }^{(6)}$ & $\begin{array}{c}\text { 74歳 } \\
\text { 女 }\end{array}$ & イレウス & 小指謴大 & $\begin{array}{l}\text { ヘルニア亳 } \\
\text { 腹膜維合 }\end{array}$ & 7 カ月 & $\begin{array}{l}\text { 左閉銷孔 } \\
ヘ ル コ \text { 再発 }\end{array}$ & 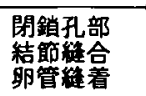 & 治里 \\
\hline 桜井 ${ }^{61}$ & $\begin{array}{c}80 \text { 歳 } \\
\text { 女 }\end{array}$ & & & $\begin{array}{l}\widehat{\text { 䋖 }} \text { 合 } \\
\end{array}$ & & & $\begin{array}{l}\text { 閉銷膜 } \\
\text { 閉銷 }\end{array}$ & \\
\hline 自战例 & $\begin{array}{c}\text { 81瓷 } \\
\text { 女 }\end{array}$ & イレウス & 小指頭大 & $\begin{array}{l}\text { ヘルニア曹 } \\
\text { 腹膜維合 }\end{array}$ & 3 年 6 力月 & $\begin{array}{l}\text { 需着性 } \\
\text { イレゥス }\end{array}$ & 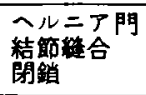 & 治耍 \\
\hline
\end{tabular}




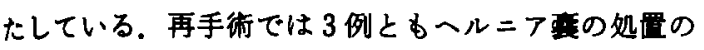
みではなく、へルニフ門の閉鎖をはかり治空している。 本症の多くは手術時全身状態が悪く，ヘルニフ門の閉

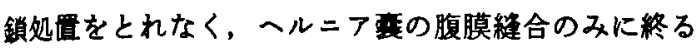
ことが多いが，患者の一般状態や局所の所見が許せば ヘルニア門を閉鎖する術式が望まれる。

本症では腸切除例が $62 \%$ に達しており，死亡率す 高く早期診断, 早期手術の重要性が示唆される. 高龄 でやせた女性のイレウスでは本症もその原因の一つで あることを想起する必要があろう。

$$
\text { まとめ }
$$

今回われわれは比較的稀な閉鎖孔へルニアの3手術 例を経験した。そのうち1例は再発をきたし，再手術 により治悹せしめた。 また本邦報告例の集計について 速べた。

本症の報告例数は近年増加傾向にあり，その手術成 家向上してきている。しかし手術死亡率はいまだ低 值ではなく，早期診断，早期手術の重要性が示唆され た. 手術々式では局所の所見と全身状態が許せばール ニフ門の絴合閉鎖が望まれる。

役後に恩師の森田教授の御高閲に感謝します，本論文の 要旨は，昭和55年11月29日第 42 回日本臨床外科学会総会て 発表した。

\section{文献}

1）尼川统史，佐々木裹，加藤永史他：閉顉孔ール = 了应例追加。外科治療，25：705-713，1971.

3）首野千治，遠藤害幸，齐藤和好他：閉鎖孔へル二 フの 1 例扰よび本邦報告例の統計的観察. 外科治 痖, $39 ： 1097-1101,1978$.

3）渡辺 た, 成田博美, 稲本純三他：閉鎖孔へル二 73 治銩例および本邦報告例の珫計的钼察。外科 診㞠, $19 ： 993-998 ， 1977$.

4）饭塚康公：閉鎖孔へルニ72 例. 外科, 39 : 191-192, 1977.

5）桜井辉久，正田裕一，小基公孝他：閉鎖孔へル二 7 の 3 治㐿例。日外会誌，79：162，1978.

6）衛藤俊二, 清家育郎, 阿部暂夫他：比較的珍らし いヘルニ 72 症例（閉鎖孔および白線へルニフ）. 神奈川医学雑誌, $5: 51,1978$.

7）掦 伯二, 可西右使, 巴陵宣彦他：腸閉塞を主訴 としたかんとんへル =フの2 例. 日外会誌，79： 1389, 1978.

8）黑田弘之, 岩崎 誠, 田中 誠他：閉鎖孔へル二 アの一治検例. 三重医学雑誌，21：580，1978.

9）久野克也，川野和婎：閉鎖孔へルニフの一例。日
外会誌, $77 ： 1124,1976$.

10）山形尚正, 杉山雄一, 上田 博他：閉鎖孔へル = フの一例。臨床外科，34:1319-1320，1979.

11）紙田信彦, 山口着友, 徳田均他: 閉鎖孔へル二 74 症例一特飞早期猃断について。外科診療, 20 ： 374-377, 1978.

12）苩野千治，遠藤害幸，嬴藤和好他：閉鎖孔へル= フの 2 例. 外科, $40: 622-625,1978$.

13）松田宏一，蔌池功次，飛鋪地二他：閉鎖孔ール二 >の一治検例。日臨外会誌，40：143，1979。

14）田中泰三, 西鴄義信, 木戸晋他：閉鎖孔へルニア の一例. 日外会誌，80：559，1979.

15）近藤 建，加藤芳正，松田真佐男她：衍前に診断 しえた閉鎖孔へルニフの一治唋例.日外会誌, 80： 297, 1979.

16）野村義信, 金 京史, 塩田隆三他：閉鎖孔へル二 フの一例。 日外会誌，80：183，1971.

17) 津田 洋, 高谷信行, 生野洋他：閉鎖孔へル二 7の一例。四国医学雜誌，35：138-139，1979.

18）寺田信國, 上田泰章, 藤䅄千噚 他：回腸想室を内 容とした閉鎖孔へルニフの治験例。外科診療, 22： 909-912, 1980.

19）小西 洋, 九畐勝美，近藤日出海他：閉鎖孔一ル = 7 の 2 治験例. 外科診㫫，6：761-765，1979.

20）日野恭徳，山城守也，中山夏太郎他：閉鎖孔へ儿 二フの診断と治療，42：816一820，1980.

21）石井郁夫，岡村治明，如部吉男他：Saint's triad の 一例. 外科, $41: 511-514,1979$.

22) Gray, S.W., Skandalakis, J.E., Soria, R.E., et al. : Strangulated obturator hernia. Surg., 75 : 20-27, 1974.

23）小島当三，山浦廉行，坂本哲夫他：新生児の閉鎖 孔ヘル 小児科診療， $27 ： 8 ， 1964$.

24) Joseph, W.L., Kipen, C.S., Longmire, Jr. W.P., et al. : Obturator hernia as a cause of of acute intestinal obstruction. Am. J. Surg., $115: 301$ $-306,1968$.

25) Anson, B.J., McCormack, L.J., Cleaveland, H.C., et al. : The anatomy of the hernial regions III. Obturator hernia and general considerations. Surg. Gynecol. \& Obst., 90 : 31-38, 1950.

26) Sommel, A., Ljungdahl, I., Spangen, L., et al. : Thigh neuralgia as a Symptom of obturator hernia. Acta Chir. Scand., 142 : 457-459, 1976.

27) Wakeley, C.P.G. : Obturator hernia. Its aetio- 
logy, incidence, and treatment, with two personal operative cases. Brit. J. Surg., 26: 515 $-525,1939$.

28) Archampong, E.Q. : Preoperative diagnosis of strangulated obturator hernia. Post. Med. J., $44: 140-143,1968$.

29) Martin, N.C. and Welch, T.P.: Obturator hernia. Brit. J. Surg., $61: 547-548,1974$.
30）日野恭徳，山城守也，中山臬太郎他：高路者閉銷

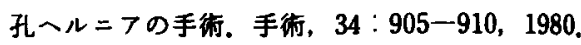

31) Shackelford, R.T.: Surgery of the alimentary tract. Philadelphia, 1955, W.B. Saunders Company, 2369-2377.

32）武沼 滋，木村正昭：閉鎖管へルニフの一治検例. 医療，15：55-58，1961. 